\title{
Feasibility of Prototyping the Jominy Test Device: Corroborating for Studies and Preliminary Results of the Heating and Data Acquisition Subsystems
}

\author{
Giulliano A. S. Boaventura ${ }^{*}$, Ramon 0. B. Santos ${ }^{1 \# ~(1), ~ R e n a n n ~ P . ~ G a m a ~}{ }^{1}$, Regina E. S. Cabette ${ }^{1}$, \\ Mariana F. B. Motta1, Cesar A. Botura1, Adriano C. M. Rosa ${ }^{2}$, Any M. Rosa ${ }^{3}$, Wilson F. Muniz ${ }^{1}$, \\ Carlos D. Jaeger ${ }^{1}$, Luiz F. F. Honorato', Thiago A. Bimestre ${ }^{1}$, Edward P. I. Silva1 ${ }^{1}$, Beatriz Santos ${ }^{1}$, \\ Livya V. M. Oliveira1, Theresa C. G. Venuto', Henrique C. Sampaio', Samuel F. V. Silva1, \\ Izabela F. L. Calazans ${ }^{1}$, Felipe A. Santos ${ }^{1}$, Fagner C. F. Santos' ${ }^{1}$, Fernando H. A. Oliveira ${ }^{1}$ \\ ${ }^{1}$ Department Mechanical Engineering, Salesian University Center of Sao Paulo (UNISAL), São Paulo, Brazil \\ ${ }^{2}$ Department Management and Business, State College of Technology (FATEC), São Paulo, Brazil \\ ${ }^{3}$ Department Mathematics, International University Center (UNINTER), São Paulo, Brazil \\ Email: *giulliano.boaventura@unisal.br, "ramonobs98@gmail.com
}

How to cite this paper: Boaventura, G.A.S., Santos, R.O.B., Gama, R.P., Cabette, R.E.S., Motta, M.F.B., Botura, C.A., Rosa, A.C.M., Rosa, A.M., Muniz, W.F., Jaeger, C.D., Honorato, L.F.F., Bimestre, T.A., Silva, E.P.I., Santos, B., Oliveira, L.V.M., Venuto, T.C.G., Sampaio, H.C., Silva, S.F.V., Calazans, I.F.L., Santos, F.A., Santos, F.C.F. and Oliveira, F.H.A. (2021) Feasibility of Prototyping the Jominy Test Device: Corroborating for Studies and Preliminary Results of the Heating and Data Acquisition Subsystems. Journal of Materials Science and Chemical Engineering, 9, 23-38. https://doi.org/10.4236/msce.2021.93003

Received: February 2, 2021

Accepted: March 23, 2021

Published: March 26, 2021

\begin{abstract}
This work contributed to a detailed study on a better understanding of the Jominy test, adopted a proportion of study to create the Jominy test device, exhibited favorable conceptions for the development of a prototype of the device, covering the four aspects of the project, being they: test device, test body heating system, test automation and instrumentation using embedded electronics and financial analysis for the elaboration of this project in Brazil. It was possible to observe in the results that the system is efficient, simple and functional, it was possible to obtain the first test carried out in the controlled environment the temperature data in degrees centigrade, the recorded data were automatically launched in Microsoft Excel by the PLX DAQ software, making the acquisition of the data. In the matter of preparing the test device, the drawings are presented in the $3 \mathrm{D}$ modeling software, cost tables of the materials used for assembly in Brazil. In terms of the heating system, a heating system was adopted that uses electromagnetic induction, the cost of materials related to the heating system design was also presented. Another relevant factor that contributes to the research and improvement of the prototype is the municipality, located in the Paraiba Valley region, located in the state of São Paulo, consisting of a fertile and relevant scenario of regional, national, international and multinational statistics, thus concluding the effectiveness for the mainly metallurgical industries. The results obtained were satisfactory
\end{abstract}


Copyright ( 2021 by author(s) and Scientific Research Publishing Inc. This work is licensed under the Creative Commons Attribution-NonCommercial International License (CC BY-NC 4.0). http://creativecommons.org/licenses/by-nc/4.0/ and consistent, when they were created for the Jominy test device with the ability to submit small pieces for testing and mainly essential in the didactic point of view for a higher education institution of engineering and technology.

\section{Keywords}

Tempering, Jominy Test, Data Acquisition, Heating

\section{Introduction}

In Brazil, according to [1], currently $96 \%$ of steel production is located in the Southeast Region, with $14.3 \%$ of the production park located in the state of Espírito Santo. According to Figures 1-3, steel production in the world and how Brazil fits into this scenario can be observed.

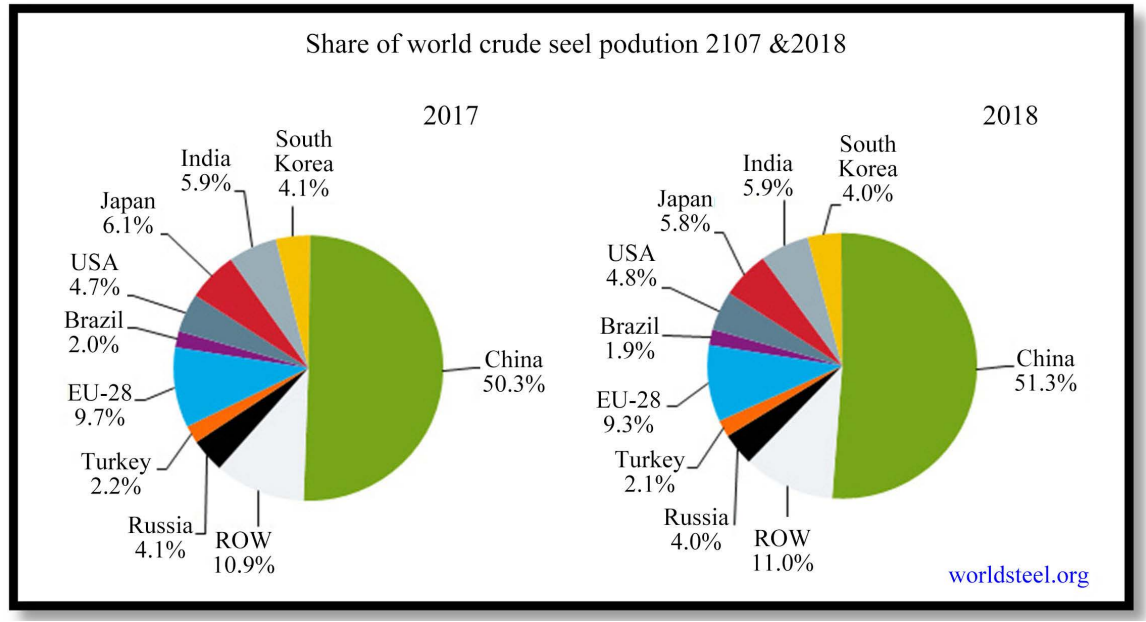

Figure 1. Steel production in the world between 2017 and 2018.

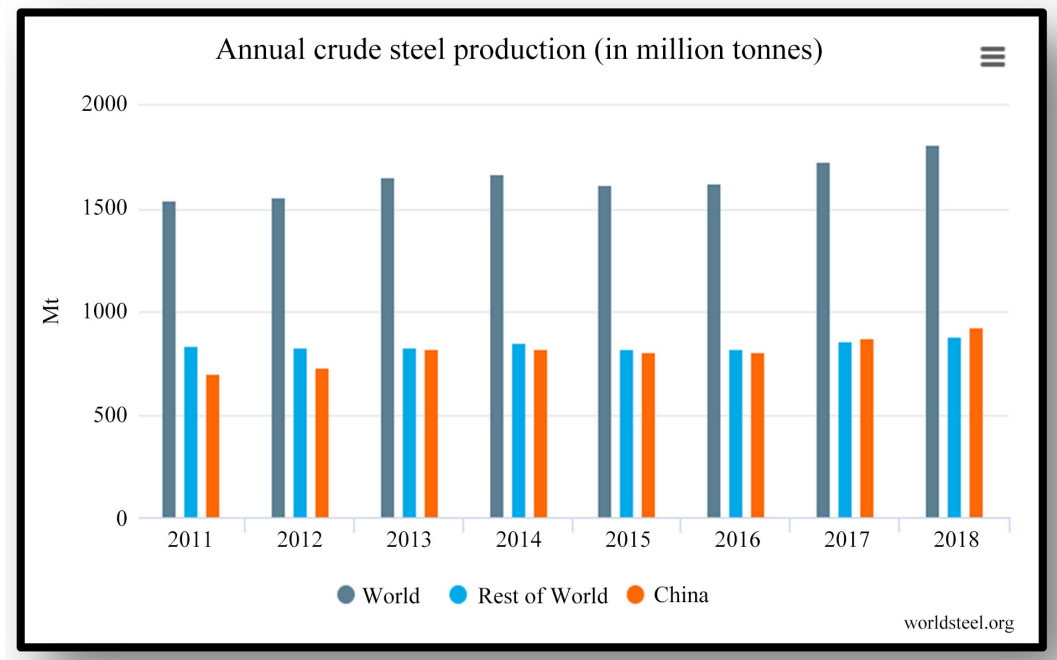

Figure 2. Annual steel production in millions per tonnes. 


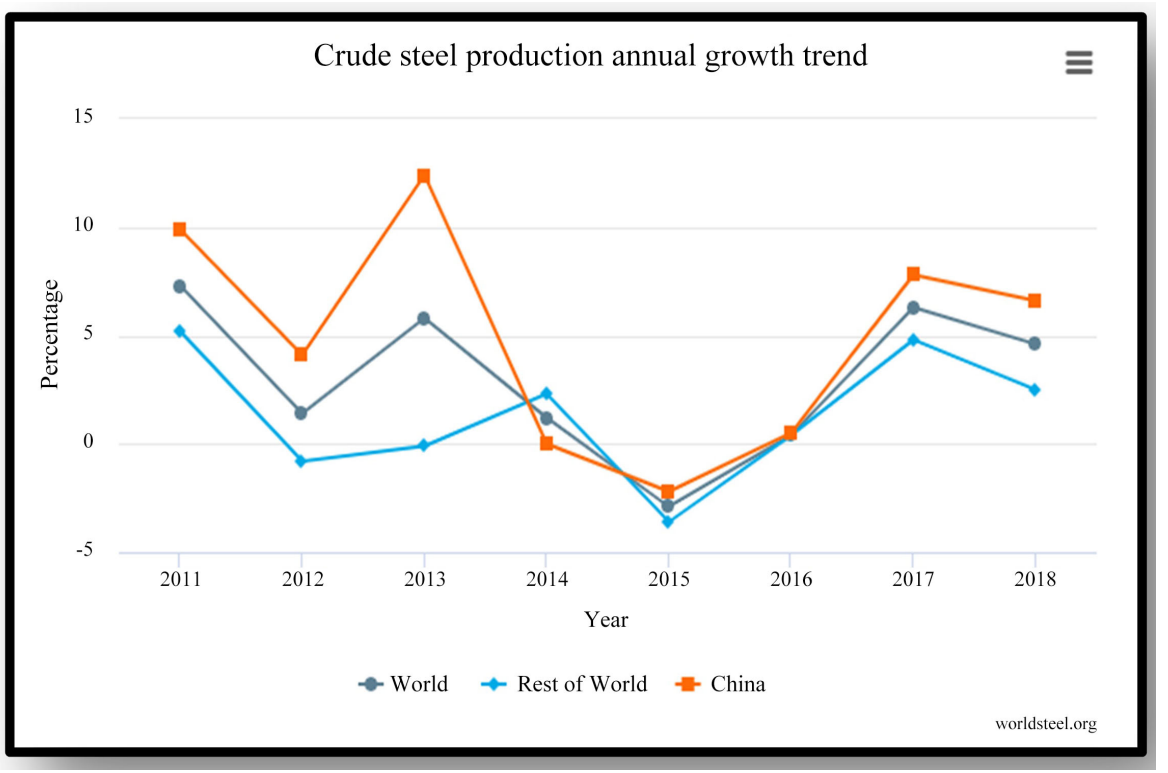

Figure 3. Annual growth trend of crude steel production.

Iron and steel production has always been a technology well known to contemporary man. Due to the needs of the time, the binary alloy from iron and carbon known as steel stood out in this scenario. Through many studies developed on steel and its use on a large scale, the mechanical characteristics of this metal were very well fixed and established in the engineering knowledge of the time [2].

Table 1 shows the largest steel producing countries.

It is estimated that iron was discovered in $1200 \mathrm{BC}$, which is considered the last technological and cultural stage of prehistory. Its discovery generated, and has been generating, great changes and revolutions throughout society [2].

In this sense, it is still emphasized that man from antiquity to modern society today very well established, always presented the need for the use of metals.

The uses of metals have always been constant in the man's life, since prehistory. The first records were the use of bronze and copper in the production combat tools and hunting tools, needing resistant utensils in combat and production of rigid instruments for everyday use of the time. After the iron age around $1200 \mathrm{BC}$, many studies were carried out until the discovery of steel after the application of carbon in iron, it was noted that the material resulting from this binary alloy, had characteristics mechanics other than conventional iron. And they could be applied in different segments of that time [2].

Steel is present in everything around us, and its ease of combining alloy elements with carbon percentages makes its applicability immense. For this purpose, this very important material in the global scenario is composed mostly of iron and carbon, with the presence of alloying elements as well. The percentage of carbon ranges from $0.008 \%$ reached at room temperature, up to about $2.11 \%$ that can be reached under the temperature of $1421.15^{\circ} \mathrm{K}[3]$. 
Table 1. Largest steel producing countries.

\begin{tabular}{ccccc}
\hline Rank & Country & 2018 (Mt) & 2017 (Mt) & \%2018/2017 \\
\hline 1 & China & 928.3 & 870.9 & 6.6 \\
2 & India & 106.5 & 101.5 & 4.9 \\
3 & Japan & 104.3 & 104.7 & -0.3 \\
4 & United States & 86.7 & 81.6 & 6.2 \\
5 & South Korea & 72.5 & 71.0 & 2.0 \\
6 & Russia & 71.7 & 71.5 & 0.3 \\
7 & Germany & 42.4 & 43.3 & -2.0 \\
8 & Turkey & 37.3 & 37.5 & -0.6 \\
9 & Brazil & 34.7 & 34.4 & 1.1 \\
10 & Iran & 25.0 & 21.2 & 17.7 \\
\hline
\end{tabular}

Steel is a metal alloy formed essentially by iron and carbon, with its carbon content ranging between $0.008 \%$ and $2.11 \%$. It is distinguished from cast iron, which is also an alloy of iron and carbon, but with carbon content between $2.11 \%$ and $6.67 \%$. The fundamental difference between the two is that steel, due to its ductibility, is easily deformable by forging, lamination and extrusion, while a cast iron part is manufactured by the casting process.

In the current stage of society development, it is impossible to imagine the world without the use of steel. Steel production is a strong indicator of a country economic development stage.

It is an extremely important component for the entire economic cycle due to the joining of several productive means. The Brazil Steel Institute points out that in February 2020, Brazilian steel mills produced approximately 5.69 thousand tons of metal.

The increase of world requirements for improved products joined to growing competition between companies in the global market makes the same seek processes that ensure lower costs allied to high productivity and high quality product [4].

Steel can be reused fully, and properties maintained during the recycling process. The use of scrap also reduces the costs of iron ore plants and reduces the use of natural resources such as coal. Another important fact that highlights the importance of the engineering professional is to know in depth the industrial process which is inserted, because his knowledge and experiences reflect directly on the problems encountered. According to [5], properties found in materials such as high tensile and fatigue resistance, good toughness, high hardness and formability make their machinability inferior. Thus, the engineering professional, who knows these properties in depth, can intervene in several problems in the industry, solving or preventing it from occurring.

The points out that the concept of temperability is linked to the hardening capacity of steel during rapid cooling, that is, its ability to form martensite, at a certain depth of metallic surface, the most used methods to evaluate temperabil- 
ity are the critical cooling rate, Grossman test and Jominy assay.

At the critical cooling rate corresponds to the lowest rate that can be used for the entire structure to be martensitic, being a simple method that can be used directly in the CCT curve (Continuous cooling transformation) of the steel. There is a difficulty in using this method because the survey of these curves requires sophisticated equipment in addition to specialized personnel in the area. In view of this, we opted for the development of simpler trials such as Grossman and Jominy.

The Grossman assay method consisting of the queering of several specimens, of the same material, but of different diameters, subjecting them to metallographic analysis and hardness tests in order to determine the critical diameter, having some limitations as a series of bars with different diameters to determine the critical diameter.

Intending to acquire a faster, Jominy showed a test using a single bar of one inch in diameter and four inches long, the bar is austenitized, that is, it is carried above its critical temperature, then cooled by a jet of water at room temperature. After being cooled, a ground track is made longitudinally in the sample and its hardness is measured from the cooled end. Each treatment has a different purpose and execution, such as cooling time and different temperatures.

Tempering is of great importance for other heat and thermochemical treatments to be carried out successfully. In a very comprehensive way it can be said that the tempering consists of heating the piece at a high temperature, reaching its austenitic phase, and cooling it quickly, in burned oil, water or brine, these steps ensure that the piece acquires considerable hardness values.

The Jominy assay consists of a steel specimen, 1.0" in diameter and 4.0" in length, being heated to austenetization temperature and cooled by means of an ascending water jet. After this process it is necessary to measure the hardness, and the hardening response is obtained as a function of the distance from the temperate end. The process goes through the following steps: the specimen is embedded in a cooling system, after being heated to the austenitization temperature, and is subjected to a water jet in vertical upward form, with temperature between $278.15^{\circ} \mathrm{K}$ and $303.15^{\circ} \mathrm{K}$.

Jet control can be done through a valve and the waterjet distance from the specimen should be 1/2", according to Figure 4, the Jominy test device can be seen.

It is important to note that the ABNT NBR 6339 standard governs the Jominy Assay. In practical terms, most component parts for heat treatment are mostly non-symmetrical. Hence, there are distortions associated with the temperature gradient set up due to differences in the thickness. The temperature gradient varies with time, being less steep at later times. Thus the temperature of the centre lags in time behind the temperature of the surface. This means that cooling rate varies as a function of depth. The greater the depth, the slower the cooling rate. Different cooling rates can lead to different hardness in the centre than at edge. The edge could transform to martensite and centre to pearlite [6]. 


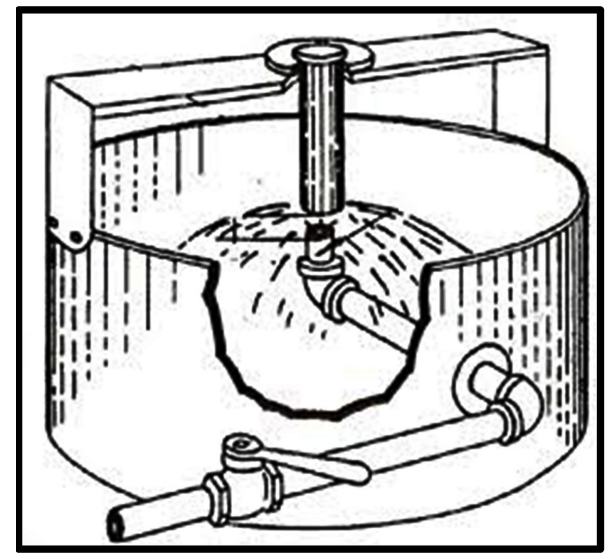

Figure 4. Device jominy essay.

An experimental design can thus be used to determine the optimal values of raw materials needed [7].

It is desirable to produce heat-treated quenched samples to a desirable hardness and homogenous structure across the section thicknesses, particularly for non symmetrical casting. To avoid variable properties across section thickness, quenching must be rapid enough to prevent the nose of the cooling curve after the material is maintained at a constant temperature within martensite start (Ms) and martensite finish (Mf) range. However, this may not be the case for thick sections because the interior cools more slowly than the surface. But if one could modify this steel such that critical cooling rate is lower than thick pieces, it can be hardened throughout and even thicker pieces can be hardened to a considerable depth. This is of great practical importance in terms of our ability to produce a fully hardened part (which will also be fully brittle), and because subsequent tempering will be successful in producing the desired strength and ductility throughout the part. In addition, one could use less severe quenches to avoid problems with warping and cracking [6].

\section{Phase Diagram}

The phase diagram presents a lot of information about the microstructure of the material, being very useful for analyzing and predicting phase transformations. Through it we can observe the time and temperature necessary to achieve several phases of steel. According to Figure 5, the iron-carbon phase diagram can be seen.

It is possible to observe in the graph three major phases: austenite $(\gamma)$, cementite $\left(\mathrm{Fe}_{3} \mathrm{C}\right)$, delta iron $(\delta)$ and ferrite $(\alpha)$. The three differ by carbon distribution. The austenitic phase has the most dissolved carbon, the cementite carbon is not dissolved with a great efficiency and in ferrite the carbon is distributed to the sides. The phases of steel is knowled was cementite, ferrite, pearlite, austenite, martensite, troostite, sorbite and bainite are some micro structures of the metal phases from steel alloy. 


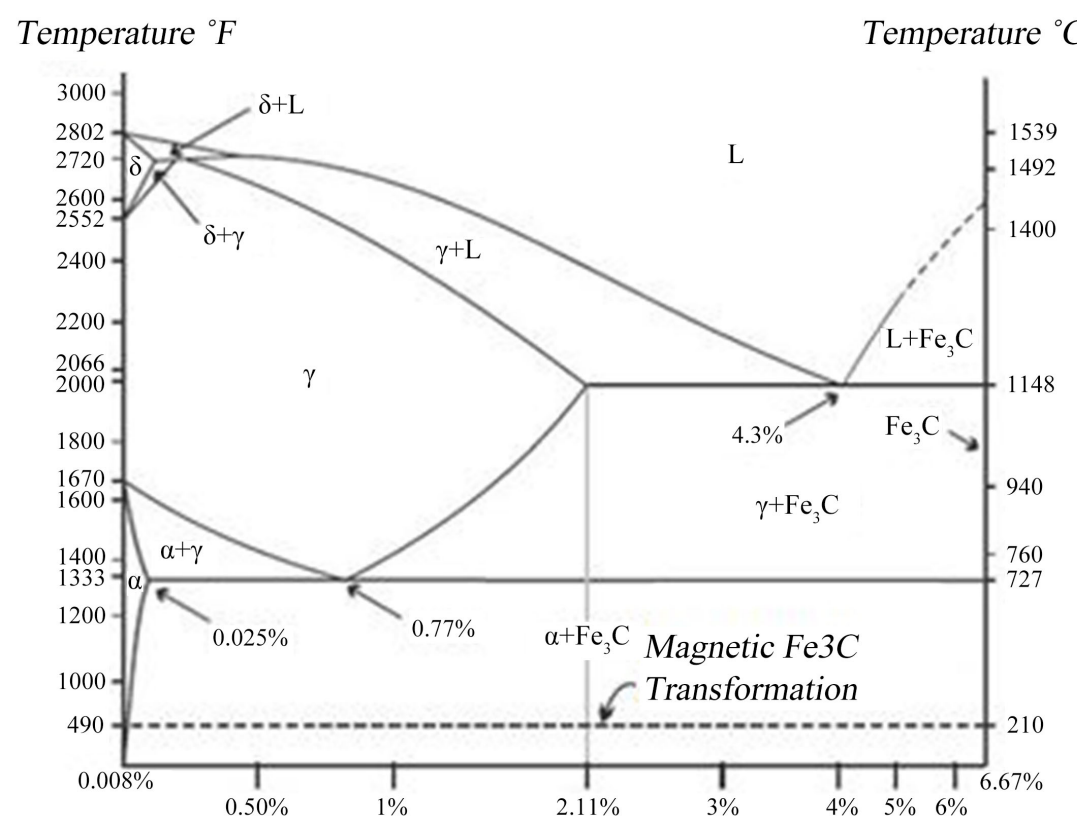

Figure 5. Iron-Carbon phase diagram.

\section{Jominy Test Machine and Specimens}

\subsection{Visual Representation}

According to [8] Continuing, for a better visualization was determined a necessary development of the design using the Auto CAD software, being illustrated in Figure 6.

For the realization of the base, a steel corner of $1 " \times \frac{1}{8}$ ", was used, thus making a base and its support according to the sketch, with a total dimensional of $750 \times 600 \times 600 \mathrm{~mm}$.

And above the base where the cooling process with stainless steel plate will be carried out in its wrapped with a device of fixing the specimen with the $\varnothing 28$ $\mathrm{mm}$, and a galvanized tube of $\varnothing \frac{1}{2} "$ at the bottom for extraction of the liquid that is used to cool the specimen.

According to [9] cad software (Computer Aided Design) are framed as graphic tools supported by computer technology, whose objective is the development of drawings and projects applied to the most diverse areas of engineering, architecture, design, industrial design and visual communication, providing commands and environments for graphic representation with a high degree of precision and static and dynamic visual resources that enable the control of the development process.

\subsection{Survey of Costs and Materials}

Table 2 shows the list of materials used in the project.

The worldwide demands for better products and better manufacturing systems contribute to increasing competition between companies [2]. 

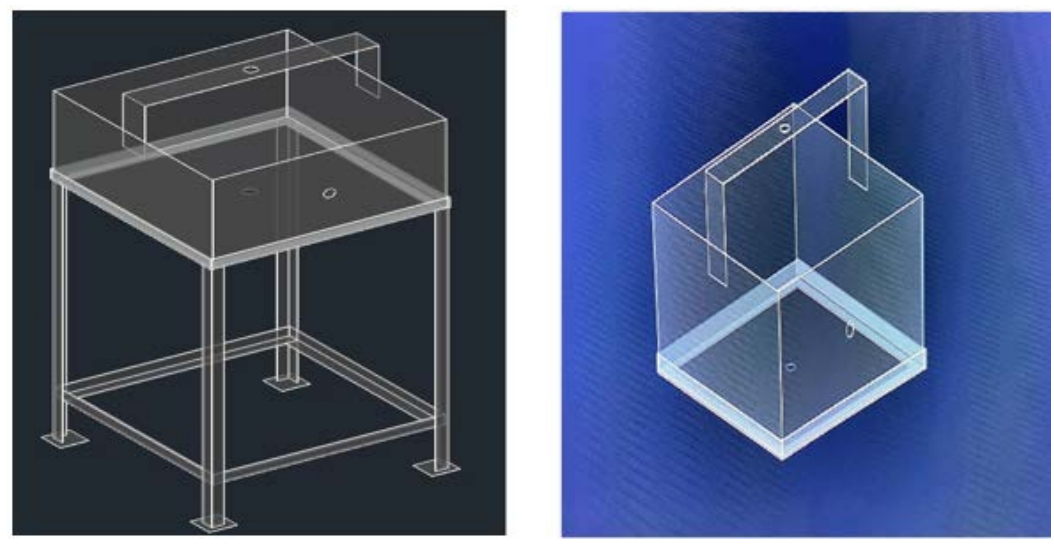

Figure 6. Jominy device 3D illustration.

Table 2. List of materials.

\begin{tabular}{|c|c|c|}
\hline Material Description & Properties & Values \\
\hline 304 stainless steel plate-Measures: $2000 \times 250 \times 1.5 \mathrm{~mm}$. & 1 piece & $\mathrm{R} \$ 220.00$ \\
\hline 304 stainless steel plate-Measures: $600 \times 600 \times 1.5 \mathrm{~mm}$. & 1 piece & $\mathrm{R} \$ 100.00$ \\
\hline Stainless steel plate $304-$ Measurements: $1000 \times 150 \times 1.5 \mathrm{~mm}$. & 1 piece & $\mathrm{R} \$ 50.00$ \\
\hline Carbon steel angle bracket-Measures: 1" 1/8" & 6 meters & $\mathrm{R} \$ 35.00$ \\
\hline Smooth carbon steel plate. $1 / 4 "$ thickness - Measures $70 \times 70 \mathrm{~mm}$. & 4 pieces & $\mathrm{R} \$ 40.00$ \\
\hline 1/2" Full ass ball valve & 2 pieces & $\mathrm{R} \$ 72.00$ \\
\hline 1/2" BSP galvanized pipe & 3 meters & $\mathrm{R} \$ 40.00$ \\
\hline 1/2" BSP galvanized sleeve & 2 pieces & $\mathrm{R} \$ 10.00$ \\
\hline Spigot $1 / 2 " \times$ Male Thread 1/2" BSP In Brass & 2 pieces & $\mathrm{R} \$ 30.00$ \\
\hline $90^{\circ}$ BSP $1 / 2 "$ Galvanized Pipe Elbow & 2 pieces & $\mathrm{R} \$ 10.00$ \\
\hline 1040 Carbon steel alloy billet-Measures 1.1/4" × $105 \mathrm{~mm}$ (specimen). & 1 piece & $\mathrm{R} \$ 20.00$ \\
\hline 4140 Carbon steel alloy billet-Measures $1.1 / 4 " \times 105 \mathrm{~mm}$ (specimen). & 1 piece & $\mathrm{R} \$ 40.00$ \\
\hline Total for Implementation Project & & $\mathrm{R} \$ 667.00$ \\
\hline
\end{tabular}

\subsection{Selected Materials}

Two different types of steels were selected in tempering, being SAE 1040 steel and SAE 4140 steel alloy, this was decided to verify the different measurements and results between the two, due to their certain TTT curves. The TTT curves consist of a diagram that describes what happens to steel, through a cooling at different speeds, at several temperatures below $996.15{ }^{\circ} \mathrm{K}$, observing the isothermal transformation of austenite into perlite.

\section{- Steel alloy SAE 1040}

This type of steel is usually used in forged parts, distribution bar, connecting rod, shaft, damper rod, brake lever, anchoring screw. It should be noted that SAE 1040 steel alloy has a low carbon percentage, which makes its TTT curve extremely narrow. Thus, there is a factor that makes it difficult to obtain the martensitic constituent, that is, it hinders the treatment of tempering, making it 
necessary a sudden cooling less than one second to reach $100 \%$ martensite. It is important to note that if several tests are made for the same type of steel alloy as 1040 , there will be a difference in results, this is due to the size of the grains, inclusions, etc. A 1040 steel alloy may have as a rule its carbon content ranging from $0.37 \%$ to $0.44 \%$, which clearly interferes with the final result.

\section{- Steel alloy SAE 4140}

The SAE 4140 Chromium-Molybdenum Carbon Steel Alloy (Villares VL-40 or WNr/DIN 1.7225) is a steel alloy that is more resistant than ordinary carbon steel. Chromium and Molybdenum improve the steels response to heat treatment tempered and enable greater mechanical resistance [10].

It is a medium temperability processing steel, used in the manufacture of different mechanical components, has a good combination of medium mechanical strength and fracture resistance and also has high fatigue resistance.

This material facilitates the test because its curve is not as narrow as that of SAE 1040 steel alloy, this makes it possible to obtain the martensite constituent without the need for more robust or expensive equipment. In this way, we contribute not only to the success of the project, but also to the financial issue, saving with equipment and energy.

\subsection{Specimens}

In the construction of the Jominy apparatus, one of the most important details of adjustment, it is related to the alignment of the specimen and the water jet that will make its cooling. Therefore, the construction and proper alignment of a specimen has full relevance, therefore, they will be done according to the NBR6339 standard to determine the measures to be followed. According to Figure 7 , the dimensions of the Jominy specimen can be observed.

The major shaft is $\varnothing 25.5 \frac{+0.5}{-0.0} \times 98 \mathrm{~mm}$, and the "head" $\varnothing 32 \frac{+0.0}{-0.3} \times 3 \mathrm{~mm}$.

\section{Heating System}

\subsection{Electromagnetic Induction}

When a conductor undergoes magnetic induction flow variation, an electromoth force is created, being an electrical potential. If these terminals are connected to an electrical appliance this electrical potential will generate an electrical current, called induced current. This phenomenon is called electromagnetic induction.

The well-known Lenz Law argues that the induced current has the opposite direction to the direction of the variation of the magnetic field that generates it, that is, if there is a decrease in the magnetic flux the induced current will create a magnetic field with the same direction of the flow and if there is an increase in the magnetic flux the induced current creates a magnetic field with a direction opposite that of the flow.

When a magnetic flux varies through a solid surface there is creation of an induced current on it as if every surface were composed of a combination of thin and juxta posed turns. 


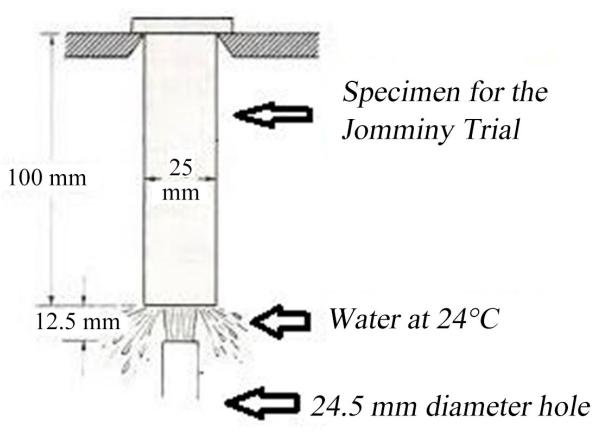

Figure 7. Specimen dimensions for the jominy test.

\subsection{Induction Heating}

Induction heating is a fast, efficient and accurate method. It is possible to be made without contact in the heating of metals. The induction heating system consists of a power supply that converts the network energy into an alternating current, which is transmitted to an induction coil, creating an electromagnetic field inside the coil. The part to be heated is placed inside the coil, the magnetic field then induces a current in the part, which produces heat. According to Figure 8 it is possible to see a real representation of the electromagnetic induction.

Induction heating is used in processes with low temperatures such as 373.15 ${ }^{\circ} \mathrm{K}$ up to high temperatures such as $3273.15{ }^{\circ} \mathrm{K}$. It can be used in short heating processes that last less than half a second and in heating processes that can last for months.

Main advantages of induction:

- Rapid heating;

- Precise and repeatable heating;

- Efficient heating;

- Safe heating, because there are no flames.

\subsection{Foucault Chains}

Known as parasitic current, it is the current induced inside the conductive inductor by means of a variable magnetic field, or even by electromagnetic radiation.

Every conductive mass that interrupts the magnetic flux ends up generating a variation in this flow and thus ends up transforming all this into electromotive force induced in the mass.

One of the effects generated by foucault current is the release of energy by Joule effect, this is due to the fact that the metal that is cutting the magnetic flux is a massive block and this causes an increase in temperature, enabling a rapid heating in a short period.

\subsection{Material Collection}

Table 3 shows the list of materials used in the project to build the heating system. 


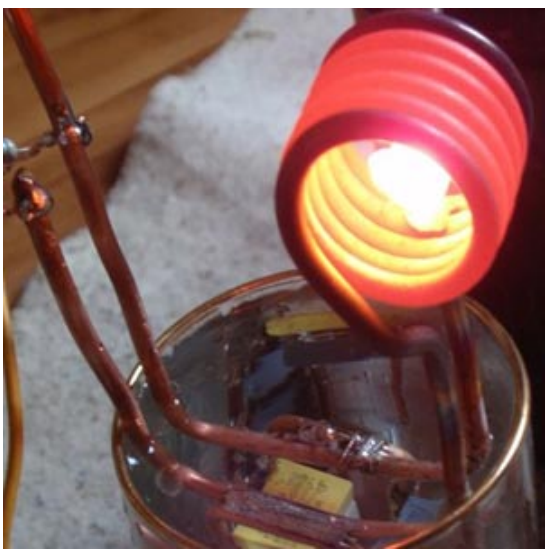

Figure 8. Example induction heating.

Table 3. Materials needed for construction project of heating.

\begin{tabular}{cc}
\hline Quantity & Components \\
\hline 2 units & IRFZ mosfet with heat sink \\
2 units & Resistors of $150 \Omega$ by $2 \mathrm{~W}$ \\
2 units & Resistors of $1 \mathrm{~K} \Omega$ by $2 \mathrm{~W}$ \\
5 units & MKP polyester capacitors $(0.33 \mathrm{mF} / 250 \mathrm{~V})$ \\
2 units & Rigid wire $\left(4.17 \mathrm{~mm}^{2}\right)$ \\
1 unity & Battery $(12 \mathrm{~V}-8 \mathrm{~A})$ \\
$1 / 2$ meter & Wire $(0.25 \mathrm{~mm})$ \\
1 meter & Flexible wire $\left(4 \mathrm{~mm}^{2}\right)$ \\
\hline
\end{tabular}

\subsection{Heating System Methodology}

The electromagnetic induction heating system heats the metals that are inserted in the inductor. Therefore it is necessary to perform the calculations of electromagnetism trimming the inductor sizing.

As for the assembly method occurs with the differentiation of flexible wires, this is necessary because one will be used in the positive pole and the other in the negative pole.

You need to cut two pieces of $15 \mathrm{~cm}$ and two of $40 \mathrm{~cm}$, both being rigid wires and bare them. The first coil of 3 turns was made using one of the $40 \mathrm{~cm}$ wires, making sure that its terminals are parallel, with the other piece of wire of $40 \mathrm{~cm}$ was made the second coil of 3 turns and welded the first in the second, thus creating a terminal in the middle of the two and a coil of 6 turns, at the end the diameter of the coil is approximately $3.5 \mathrm{~mm}$.

Subsequently, the union is performed 3 capacitors with double sided and weld the wires of $15 \mathrm{~cm}$ on each of its sides, this ensures a parallel association of the capacitors, it is important to leave terminals of $5 \mathrm{~cm}$ at their ends, front, so that so that the union can be made with the coil together at the beginning of the assembly. After performing the union of capacitors in parallel with the coil is made the union of the other end of the association of capacitors with the two mosfets. 
In the terminals of the capacitor association are welded two resistors of $1 \mathrm{~K} \Omega$ and connected in a crossway way in the mosfets and in the interconnection terminal of the two mosfets weld the negative wire.

Another piece of rigid wire of $50 \mathrm{~cm}$ is cut and with this wire is made a smaller coil with 10 turns, this is welded in the union between the two larger coils and at its other end is welded the positive wire. So simply connect the positive and negative wire to the $12 \mathrm{~V}$ and $8 \mathrm{~A}$ battery terminals.

The prototype built in class was similar to the one mentioned above. The group performed only one test, and in this it was possible to reach a temperature of $473.15^{\circ} \mathrm{K}$. With the unavailability of time and equipment due to external factors it was not possible to optimize this project, however the group believes that with the proper calculations and adjustments of dimensions it is possible to reach the necessary temperature of $1003.15{ }^{\circ} \mathrm{K}$ for the steel part to reach its austenitization temperature. According to Figure 9 illustrates what it was possible to make.

This heating system prototype has the following characteristics that can be observed in Table 4, in that table the materials used and specifications of the prototype induction heating coil are presented.

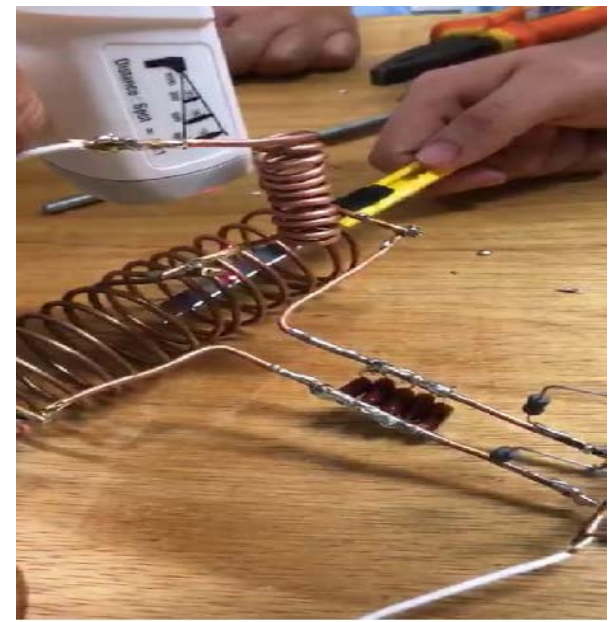

Figure 9. Prototype of induction heating.

Table 4. Materials used in the prototype of induction heating.

\begin{tabular}{cc}
\hline Components & Specification \\
\hline WIRE SECTION & $4.17 \mathrm{~mm}^{2}$ \\
WIRE DIAMETER & $2.305 \mathrm{~mm}$ \\
WIRE RESISTANCE & $4.07 \Omega$ \\
COIL DIAMETER & $30 \mathrm{~mm}$ \\
COIL LENGTH & $130 \mathrm{~mm}$ \\
SPIRAL SPACING & $6 \mathrm{~mm}$ \\
NUMBER OF SPIRITS & 15
\end{tabular}




\subsection{Improvement Proposal}

The objective of this improvement is to increase the heating capacity of the system, being possible to reach the minimum $1003.15^{\circ} \mathrm{K}$ to perform the tempering required for the test. This temperature was delimited because according to [11], when trying to reach higher temperatures such as $1123.1{ }^{\circ} \mathrm{K}$ the induction heating system will have to have another configuration, and is will cause the material to be heated very quickly and the cycles of the grain diffusion process are incomplete causing the carbon atoms not to be distributed in a uniform way.

In a Steel Alloy SAE 1040, for example, when performing this rapid heating would be provides the accumulation of carbon in the contour of its grains leaving them more rigid and may occur cracks later. Therefore, heating in a slightly slower way is beneficial the structure of the material, however in any electromagnetic induction heating, being slow or fast, tempera performed quickly after the process is required. Table 5 shows the costs of materials used in the heating system prototype.

\section{Data Acquisition System}

\section{Results}

The results obtained were relevant because in the tests to which the sensors were submitted, the results presented were plausible, the tests were carried out in a controlled environment as can be seen in Figure 10 and to simulate the heating system a $100 \mathrm{~W}$ incandescent lamp was used, the unit of measurement was centigrade degrees, so in Table 6 the results acquired by each sensor connected to the Arduino can be observed.

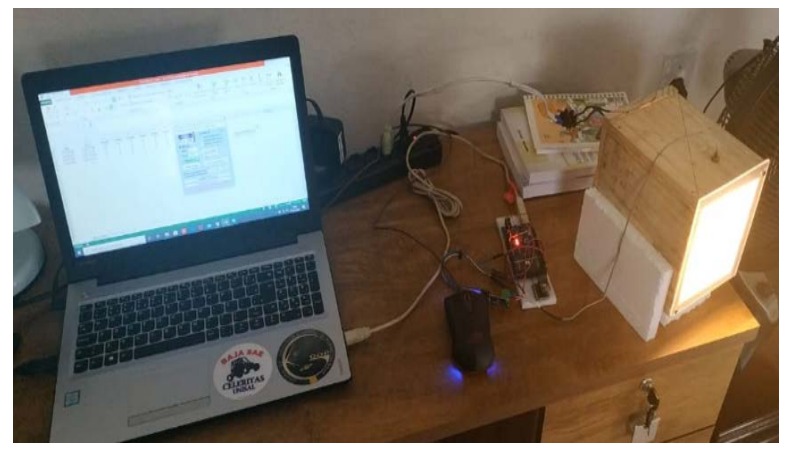

Figure 10. Temperature reading tests.

Table 5. Survey of materials and costs.

\begin{tabular}{ccc}
\hline Materials & Properties & Values \\
\hline $\begin{array}{c}\text { Sweet } \\
\text { Steel Alloy }\end{array}$ & They are steels with a very high level of impurities, due to the low & $\mathrm{R} \$ 10.00$ per \\
maximum carbon content of $0.15 \%$. & kilogram \\
Copper & High conductivity capacity, it is also a very malleable material, which & $\mathrm{R} \$ 1.52$ per \\
Wire & makes handling more practical. It can be welded and polished easily. & meter \\
Welding & It is simpler in terms of equipment needs with relatively low & $\mathrm{R} \$ 35.00$ \\
Electrode & investment cost. & \\
\hline
\end{tabular}


Table 6. Results of temperature obtained from the sensors.

\begin{tabular}{|c|c|c|c|c|c|c|}
\hline Data & \multicolumn{2}{|c|}{ temperature temperature } & Sensor 4 & Sensor 3 & Sensor 2 & Sensor 1 \\
\hline & & & & & & \\
\hline $07 / 03 / 2020$ & $77.75^{\circ} \mathrm{C}$ & $79.05^{\circ} \mathrm{C}$ & $90.50^{\circ} \mathrm{C}$ & $95.75^{\circ} \mathrm{C}$ & $84.25^{\circ} \mathrm{C}$ & $76.75^{\circ} \mathrm{C}$ \\
\hline $07 / 03 / 2020$ & $78.50^{\circ} \mathrm{C}$ & $79.50^{\circ} \mathrm{C}$ & $90.50^{\circ} \mathrm{C}$ & $94.50^{\circ} \mathrm{C}$ & $83.75^{\circ} \mathrm{C}$ & $76.50^{\circ} \mathrm{C}$ \\
\hline $07 / 03 / 2020$ & $78.75^{\circ} \mathrm{C}$ & $79.75^{\circ} \mathrm{C}$ & $91.25^{\circ} \mathrm{C}$ & $93.75^{\circ} \mathrm{C}$ & $83.50^{\circ} \mathrm{C}$ & $76.25^{\circ} \mathrm{C}$ \\
\hline $07 / 03 / 2020$ & $79.25^{\circ} \mathrm{C}$ & $79.75^{\circ} \mathrm{C}$ & $91.50^{\circ} \mathrm{C}$ & $93.50^{\circ} \mathrm{C}$ & $83.25^{\circ} \mathrm{C}$ & $76.00^{\circ} \mathrm{C}$ \\
\hline $07 / 03 / 2020$ & $80.00^{\circ} \mathrm{C}$ & $80.05^{\circ} \mathrm{C}$ & $91.75^{\circ} \mathrm{C}$ & $93.00^{\circ} \mathrm{C}$ & $83.00^{\circ} \mathrm{C}$ & $75.75^{\circ} \mathrm{C}$ \\
\hline $07 / 03 / 2020$ & $80.00^{\circ} \mathrm{C}$ & $81.75^{\circ} \mathrm{C}$ & $92.00^{\circ} \mathrm{C}$ & $92.50^{\circ} \mathrm{C}$ & $82.50^{\circ} \mathrm{C}$ & $75.50^{\circ} \mathrm{C}$ \\
\hline $07 / 03 / 2020$ & $81.05^{\circ} \mathrm{C}$ & $82.25^{\circ} \mathrm{C}$ & $92.50^{\circ} \mathrm{C}$ & $92.25^{\circ} \mathrm{C}$ & $81.75^{\circ} \mathrm{C}$ & $75.25^{\circ} \mathrm{C}$ \\
\hline $07 / 03 / 2020$ & $81.50^{\circ} \mathrm{C}$ & $82.75^{\circ} \mathrm{C}$ & $92.75^{\circ} \mathrm{C}$ & $91.50^{\circ} \mathrm{C}$ & $81.50^{\circ} \mathrm{C}$ & $75.00^{\circ} \mathrm{C}$ \\
\hline 07/03/2020 & $82.00^{\circ} \mathrm{C}$ & $83.25^{\circ} \mathrm{C}$ & $93.00^{\circ} \mathrm{C}$ & $91.75^{\circ} \mathrm{C}$ & $81.00^{\circ} \mathrm{C}$ & $74.00^{\circ} \mathrm{C}$ \\
\hline $07 / 03 / 2020$ & $82.25^{\circ} \mathrm{C}$ & $84.00^{\circ} \mathrm{C}$ & $93.25^{\circ} \mathrm{C}$ & $90.75^{\circ} \mathrm{C}$ & $80.75^{\circ} \mathrm{C}$ & $73.00^{\circ} \mathrm{C}$ \\
\hline $07 / 03 / 2020$ & $82.75^{\circ} \mathrm{C}$ & $84.50^{\circ} \mathrm{C}$ & $93.75^{\circ} \mathrm{C}$ & $90.00^{\circ} \mathrm{C}$ & $80.50^{\circ} \mathrm{C}$ & $72.75^{\circ} \mathrm{C}$ \\
\hline $07 / 03 / 2020$ & $83.50^{\circ} \mathrm{C}$ & $84.75^{\circ} \mathrm{C}$ & $94.25^{\circ} \mathrm{C}$ & $89.25^{\circ} \mathrm{C}$ & $80.25^{\circ} \mathrm{C}$ & $72.25^{\circ} \mathrm{C}$ \\
\hline $07 / 03 / 2020$ & $83.75^{\circ} \mathrm{C}$ & $85.00^{\circ} \mathrm{C}$ & $94.75^{\circ} \mathrm{C}$ & $88.75^{\circ} \mathrm{C}$ & $80.00^{\circ} \mathrm{C}$ & $71.00^{\circ} \mathrm{C}$ \\
\hline $07 / 03 / 2020$ & $84.00^{\circ} \mathrm{C}$ & $85.25^{\circ} \mathrm{C}$ & $95.00^{\circ} \mathrm{C}$ & $88.00^{\circ} \mathrm{C}$ & $79.75^{\circ} \mathrm{C}$ & $70.75^{\circ} \mathrm{C}$ \\
\hline $07 / 03 / 2020$ & $84.25^{\circ} \mathrm{C}$ & $85.50^{\circ} \mathrm{C}$ & $95.50^{\circ} \mathrm{C}$ & $87.75^{\circ} \mathrm{C}$ & $79.50^{\circ} \mathrm{C}$ & $70.50^{\circ} \mathrm{C}$ \\
\hline $07 / 03 / 2020$ & $84.50^{\circ} \mathrm{C}$ & $85.75^{\circ} \mathrm{C}$ & $95.75^{\circ} \mathrm{C}$ & $87.00^{\circ} \mathrm{C}$ & $79.25^{\circ} \mathrm{C}$ & $72.25^{\circ} \mathrm{C}$ \\
\hline $07 / 03 / 2020$ & $85.25^{\circ} \mathrm{C}$ & $86.25^{\circ} \mathrm{C}$ & $96.50^{\circ} \mathrm{C}$ & $86.00^{\circ} \mathrm{C}$ & $79.00^{\circ} \mathrm{C}$ & $72.00^{\circ} \mathrm{C}$ \\
\hline
\end{tabular}

With this it is possible to observe that in the tests in which they were submitted they presented plausible results, thus showing the effectiveness of this device for temperature data acquisition, and thus ensuring an interdisciplinary project, and can be used in several engineering segments.

The importance of works of this nature demonstrates the results of interdisciplinary knowledge in current on-demand engineering solutions in the presentation of viable alternatives that can be improved future research and in the creation of products [12].

The evolution of the human being is constant, we are always in search of new technologies, methods and techniques in order to provide several improvements such as, cost reduction, increase in quality, reduction in the use of natural resources, improvement of the workforce, agility of consequently provide improvements in quality of life [13] [14] [15].

\section{Conclusions}

At the end of this project, it was possible to obtain knowledge of various types of steels, because a whole research was carried out on steels with properties suitable for Jominy tests, besides acquiring several concepts and knowledge in various areas of mechanics, such as tempering processes, steel structures and their respective TTT and CTT curves, constituents of austenite, martensite, ferrite and 
etc. Knowing the necessary properties of the project scope, in addition to establishing the main requirements for assembling a device for Jominy testing.

The proposed system, exclusively in the first configuration developed in the faculty and which uses inductive heating with a common turn as a way to heat the steel, proved to be viable in construction and construction time issues, however it was not possible to achieve with this system the austenitization temperature of the steel. Due to the fact that the system settings, such as the diameter and spacing of the turns, are not in the proper dimensions.

In the later idea the project was sized taking into account the diameter of the coil, the spacing between its turns and the existence of a magnetic iron core to increase the inductance in its center. This system was based on the core of a simple transformer and according to research in its center the heating is optimized due to the existence of a magnetic iron material in its core. Thus, in the second configuration, according to research, the system is more efficient.

The Jominy tempera assay is used nowadays in various sectors of the industry, among which stand out are metallurgy and metallurgical. The Jominy test process is relatively simple, ensuring a consistent hardness result in the material.

The data acquisition system will be responsible for collecting data and gathering it to receive a treatment and thus acquire the hardness curve of the specimen. The communication software between arduino and computer used the PLX-DAQ. The sensors that were used the thermocouple type $\mathrm{K}$ together with module MAX6675, the sensors were correctly sized because their operating temperature range, is compatible with the temperature of the working environment, the module for Arduino MAX 6675, had the function of amplifying and conditioning the electrical signals emitted by the thermocouple sensor. Although the temperature test was performed as a $100 \mathrm{~W}$ power lamp, it was possible to obtain the accurate and expected results by the researchers. Aiming at future work, the analysis for several steels will be applied to the Jominy test device as performed according to [16] [17], a further study will also be carried out in these tests for the surface tension of the steel alloy, according to the work from [18].

\section{Conflicts of Interest}

The authors declare no conflicts of interest regarding the publication of this paper.

\section{References}

[1] Bradesco. Steel Sectorial Information. Economy in Day. https://www.economiaemdia.com.br/BradescoEconomiaEmDia/static_files/pdf/pt/ monitores/setorial/infset_mineracao_siderurgia.pdf

[2] Santos, R.O.B., Prado, P.H.C., Oliveira, L.V.M. and Gama, R.P. (2020) Metalloghaphic Analysis of SAE 1020 Steel Cavac Formation in a Turning Process per Computered Numerical Command. SODEBRAS, 15, 53-59. https://doi.org/10.29367/issn.1809-3957.15.2020.175.53

[3] Chiaverini, V. (1996) Steels and Cast Iron. 7th Edition. ABM, São Paulo.

[4] Gama, R.P. and Ribeiro, M.V. (2015) Effects of Cutting Fluid Application in the 
Performance of the Nimomic 80A Turning. Key Engineering Materials, 656-657, 243-250. https://doi.org/10.4028/www.scientific.net/KEM.656-657.243

[5] Thakur, A., Tak, M. and Mote, R.G. (2019) Electrochemical Micromachining Behavior on 17-4 PH Stainless Steel Using Different Electrolytes. Procedia Manufacturing, 34, 355-361. https://doi.org/10.1016/j.promfg.2019.06.177

[6] Yekinni, A.A., Agunsoye, J.O., Bello, S.A., Awe, I.O. and Talabi, S.I. (2014) Fabrication of End Quenched Machine: Hardenability Evaluation. Journal of Minerals and Materials Characterization and Engineering, 2, 107-113. https://doi.org/10.4236/jmmce.2014.22014

[7] Yanu, C.A., Sieliechi, J.M. and Ngassoum, M.B. (2020) Optimization of Ceramic Paste Viscosity Use for the Elaboration of Tubular Membrane Support by Extrusion and Its Application. Journal of Materials Science and Chemical Engineering, 8, 1-22. https://doi.org/10.4236/msce.2020.83001

[8] Giroto, L.G.F.F., Boaventura, G.A.S., Gama, R.P., et al. (2020) Development and Financial Analysis for the Elaboration Jominy Test Device: Conception of an Engineering Project from the Point of View Undergraduate Students. International Journal of Advanced Engineering Research and Science, 7, 331-336. https://doi.org/10.22161/ijaers.76.41

[9] Baldam, R. (2015) AutoCAD 2016: Utilizando Totalmente. Saraiva Educação SA.

[10] Aços Roman. SAE 4140 | Aço Cromo-MolibdênioRoman Steels SAE 4140 | Chrome Molybdenum Steel. https://aco.com.br/aco/sae-4140-cromo-molibdenio-cr-mo/

[11] Ferreira, C.R. (2004) Heat Treatment by Electromagnetic Induction of SAE 1045 Steel Rods for Geological Survey. Master Thesis, Federal University of Ouro Preto, Ouro Preto.

[12] do Carmo, T.A., Cabette, R.E.S. and Gomes, R.G. (2020) Prototype of Robotic Mechanical Prosthesis of Upper Limb at Low Cost. International Journal of Advanced Engineering Research and Science, 7, 22-26. https://doi.org/10.22161/ijaers.74.2

[13] Silveira, K.C.C., dos Santos, R.O.B., D’Avila, L.S., et al. (2020) The Reliability of Metrologia 4.0 Data in the Industrial Technological Scenario: How This can Impact the Forms of Dimensional Control in the Industry. International Journal of Engineering and Applied Sciences, 7, 34-38. https://doi.org/10.31873/IJEAS.7.04.05

[14] Cunha, K. and Santos, R. (2020) The Reliability of Data from Metrology 4.0. International Journal on Data Science and Technology, 6, 66-69.

https://doi.org/10.11648/j.ijdst.20200604.11

[15] Santos, F.A., Pinto, M.A.C., Santos, R.O.B., Bimestre, T.A. and Gama, R.P. (2021) Comparative Analysis of the Application of Lubricant Coolant by the MQF Technique in the Face Milling Machining Process of Hardened D2 Steel Alloy. Brazilian Journal of Development, 7, 10349-10370. https://doi.org/10.34117/bjdv7n1-703

[16] Gonçalves, E., Milanez, A., Daleff, A. and Peruchi, F. (2020) Comparative Study between Cast Steels SC 1045 and SC 4140, for Application in Gears Made by the Casting Process. Brazilian Journal of Development, 6, 95724-95737.

https://doi.org/10.34117/bjdv6n12-165

[17] Luo, M., Zhang, Z.-H., Liu, Y.-H. and Li, M.-C. (2020) Effect of Titanium and Boron Microalloying on Sulfide Stress Cracking in C110 Casing Steel. Materials, 13, 5713. https://doi.org/10.3390/ma13245713

[18] Medina-Juárez, I., Araujo de Oliveira, J., Moat, R.J. and García-Pastor, F.A. (2019) On the Accuracy of Finite Element Models Predicting Residual Stresses in Quenched Stainless Steel. Metals, 9, 1308. https://doi.org/10.3390/met9121308 